\title{
Interleukin-6 (IL-6) influence on colonic anastomosis healing in rats ${ }^{1}$
}

\author{
A influência da Interleucina-6 (IL-6) na cicatrização de anastomoses colônicas em ratos
}

\author{
Fernando Hintz Greca ${ }^{2}$,Zacarias Alves de Souza Filho ${ }^{3}$, Allan Giovanini ${ }^{4}$, Carlos Agemiro de Camargo Junior ${ }^{5}$, Michel \\ Risnic Rubin ${ }^{6}$, Ruy Fernando Kuenzer Caetano da Silva ${ }^{6}$ \\ 1. Research performed at Experimental Surgery Department of Pontifical Catholic University of Paraná (PUCPR), Brazil \\ 2. PhD, Full Professor, Experimental Surgery, PUCPR. Associate Professor, Department of Surgery, Federal University of Paraná, \\ (UFPR), Brazil. \\ 3. PhD, Full Professor, Department of Surgery, PUCPR, Brazil. \\ 4. PhD, Full Professor, Department of Pathology, Odontology School, UFPR, Positive University Center (UNICENP), Brazil. \\ 5. Surgeon, Vita Hospital, Curitiba - PR, Brazil. \\ 6. Graduate student, PUCPR, Brazil.
}

\begin{abstract}
Purpose:To observe the effect of pro-inflamatory citokin, Interleukin-6 (IL-6), administration on the healing of colonic anastomosis in rats. Methods: Thirty Wistar rats were divided into 2 groups of 15 animals each: a control group and an experiment group. The animals of the experiment group were submitted to injection of $500 \mu \mathrm{g} / \mathrm{kg}$ of IL- 6 Recombinant (Sandoz Phamarceutical ${ }^{\circledR}$ ) subcutaneously 24 and 12 hours preceding the surgery, and the control group, were submitted to the injection of saline solution, using the same volume of solution as well as the way of administration. The rats were submitted to an end to end colonic anastomosis, being sacrificed in the $7^{\text {th }}$ post-operative day, the site of the anastomosis was evaluated regarding to the adhesions that was quantified and the presence of complications was observed. The colon containing the anastomosis was submitted to a tensiometric study and a sample were sent for histological studies with HE and Sirius Red dye. Results: The macroscopic and the tensiometric study did not demonstrate any significant differences between the control and experiment group. Regarding the histological evaluation, there was a significant reduction of the chronic inflammatory process in the experiment group $(p=0,0209)$ and a lesser granulation area $(p=0,0099)$. The total amount of collagen was similar in both groups, however, the experimental group showed a predominant area of immature collagen $(p=0.009)$. Conclusions: The longer persistence of the acute phase of wound healing in the experiment group, as well as a decreased of the mature collagen type I, demonstrating that the IL-6 was harmful to the colonic healing anastomosis in rats.
\end{abstract}

Key words: Interleukin-6. Anastomosis, surgical. Rats.

\section{RESUMO}

Objetivo: Verificar a influência da administração da citocina pró-inflamatória, Interleucina-6 (IL-6), na cicatrização de anastomoses colônicas em ratos. Métodos: Utilizaram-se 30 ratos Wistar, divididos em 2 grupos, controle e experimento, de 15 animais cada. Os animais do grupo experimento receberam nas 24 e 12 horas precedentes a cirurgia, $500 \mu \mathrm{g} / \mathrm{kg}$ de IL-6 Recombinante (Sandoz Phamarceutical ${ }^{\circledR}$ ) via subcutâneo, os animais do grupo controle, receberam a administração de soro fisiológico nesse mesmo período, pela mesma via. Foram submetidos à anastomose colônica término-terminal. No $7^{\circ}$ dia pós-operatório foram realizadas a eutanásia, com quantificação macroscópica das aderências e visualização de complicações. Em seguida realizou-se o estudo tensiométrico, seguido do estudo histológico das lâminas coradas com Hematoxicilina Eosina e Sirius Red. Resultados: O estudo macroscópico e tensiométrico não demonstraram diferenças significativas entre os grupos estudados. Na avaliação histológica, os resultados significativos demonstraram uma diminuição no grupo experimento do processo inflamatório crônico $(\mathrm{p}=0,0209)$ e uma menor área de granulação $(\mathrm{p}=0,0099)$ presente neste grupo. Na densitometria do colágeno houve um percentual significativamente maior de colágeno imaturo (tipo III) no grupo experimento (70,76 +-9,47), quando comparado ao grupo controle $(56,31+-11,29), p=0,009$. Conclusões: Os resultados analisados mostraram que houve um maior número de complicações relacionados à persistência da fase aguda da cicatrização no grupo experimento, com manutenção do processo inflamatório agudo neste grupo e que a Interleucina-6, mostrou-se ser prejudicial à cicatrização de anastomoses colônicas em ratos.

Descritores: Interleucina-6. Anastomose cirúrgica. Ratos. 


\section{Introduction}

Over the past two decades, advances in protein chemistry and molecular biology have allowed the isolation and functional characterization of many cytokine mediators. Multidisciplinary researches had showed the importance of the cytokines in orchestrating the body physiologic and patophysiologic reply to diverse process ${ }^{1,2}$.

Inteleukin-6 (IL-6) is a pleiotropic cytokine whose action includes modulation, proliferation, differentiation and maturation of diverse cellular types ${ }^{1,3,4}$. It exerts an effect over the receptor channel (IL-6R) and a common signal tranductor, gp 130 , both responsible for it manifestations ${ }^{2,3}$. IL-6 elevation had been described in reply to trauma, burns and elective surgery ${ }^{1}$. In trauma its elevation is proportional to tissue damage, demonstrating a strong correlation of this rise with the hospital mortality, very similar to APACHE II. IL-6 has been the cytokine more identified in post-injury complications $5,6,7,8$.

Its action in wound healing has been studied for many surgeons, that understand that healing is harmed in patient with hipercytocinemia, however there is no established consensus ${ }^{7,9,10}$.

The IL-6 is emerging as a great importance cytokine in an elevated gamma of processes, including wound healing ${ }^{11,3}$. Therefore, the promising characteristics of IL-6 and the absence of a consensus about its role in the healing process motivated us to study, experimentally, the influence of exogenous IL-6 in the healing of a colonic anastomosis in rats.

\section{Methods}

This study was approved by the committee of ethics in animals research of the Pontifical Catholic University of Paraná in accord to the Council for International Organization of Medical Sciences ${ }^{11}$. Thirty adult Wistar male rats (Rattus norvegicus albinus, Rodentia mammalia), weighing 150 to $210 \mathrm{~g}$, were used in this experiment. The animals were allocated into two groups of 15 rats. In the experimental group $500 \mu \mathrm{g} / \mathrm{kg}$ of recombinant IL-6 (Sandoz Pharmaceutical ${ }^{\circledR)}$, were injected subcutaneously 24 and 12 hours prior to the operation. In the control group the same volume of normal saline solution was injected subcutaneously in the same interval of time by the same way. Animals were fasted from solid food overnight before surgery. The anesthesia was achieved by the administration of ketamin $(60 \mathrm{mg} /$ $\mathrm{kg})$ and xylazin $(10 \mathrm{mg} / \mathrm{kg})$ intraperitoneally. Abdominal cavity was entered though a midline incision and a transection in the left colon was performed, $4 \mathrm{~cm}$ above the peritoneal deflection, followed by an end to end colonic anastomosis with uninterrupted suture in one layer, using 8 stitches of 6-0 nylon. On the $7^{\text {th }}$ postoperative day, all animals were sacrificed with a lethal dose of the same anesthetics. The abdomen was opened through the previous midline incision. Peritoneal adhesions, abscesses and fistulas were assessed. Adhesions were classified and graded by two observers in a blind fashion as follows: $0=$ absent; $\mathrm{I}=$ thin, easily separable; II = fibrotic, requiring sharp dissection. A 5 $\mathrm{cm}$ perianastomotic segment of the colon was then removed and bursting pressure was determined as follow: catheters were inserted intraluminally at each end of the colon, containing the anastomosis, secured via 3-0 purse string suture, and then the segment was immersed in water. Air was insufflated at 1 liter per minute through one catheter. The second way was attached to a transducer and bursting pressure was recorded.

After the measurement of bursting pressures, a sample of the colon containing the anastomosis was opened by an anti-mesenterial incision and then was fixed in $10 \%$ formalin and embedded in paraffin. Sections were obtained at $4 \mu \mathrm{m}$ intervals and stained with hematoxicilin and eosin (H\&E) and sirius-red. In the sections stained with H\&E, were observed:

- Quantitatively:

-Angiogenesis, that was calculated regarded by the vascular area;

- Distance between the anastomotic loops, in mm;

- Granulation area, in $\mathrm{mm}^{2}$.

- Qualitatively:

-Inflammatory infiltrade, whose parameters were scored as chronic or not.

-Granuloma inflammatory infiltrated as chronic or not.

The specimens were also stained with Sirius Red, according to Junqueira ${ }^{12}$ et al. to evaluate the collagen I/ III ratio tissue, using cross-polarization microscopy. Thicker collagen type I fibers were stained by cross microscopy in red-orange shades, and thinner collagen type III appeared as green shades. Under an optical Zeiss microscope, with a magnification of $200 \mathrm{X}$, four areas around the anastomotic segment were selected. The images were capturated by a digital video camera and processed by a digital image analyzing software (ImagePro Plus). Then total amount of collagen was measured as percentage of collagen type I and type III of total area (Figure 1).

Quantitative variables were analysed by nonparametric Mann-Whitney test. Categorical variables were analyzed by Fisher's exact text. Statistical significance was accepted when $\mathrm{p}<0.05$. Analysis was performed with the Statistica 5.1 software package. 


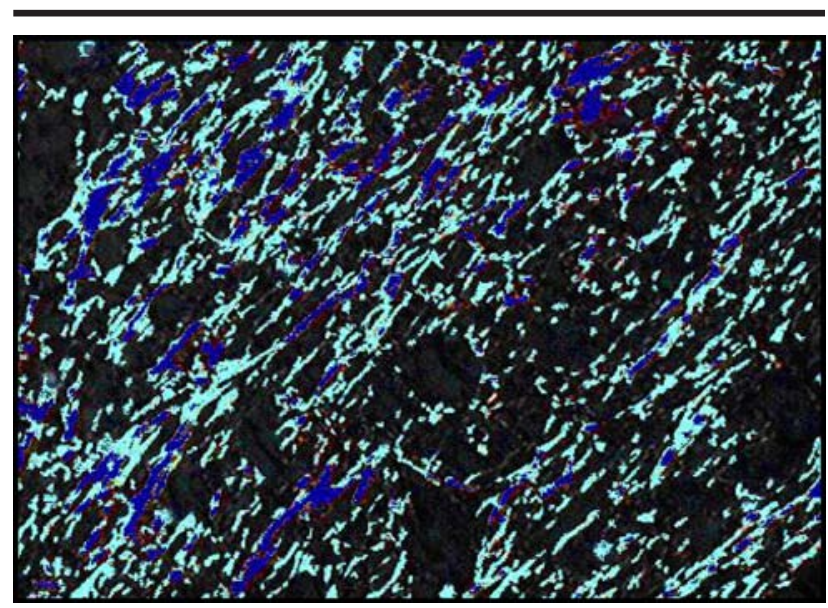

FIGURE 1 - Histologic photomicrography showing collagen densitometry with predominance of immature collagen (green shades) in experiment group

\section{Results}

During the experiment, there was no mortality in both groups of animals. In all anastomotic sites, the omentum was attached. Regarding to complications, we observed the presence of abscesses and intestinal fistulas in some cases, but the results were similar in both groups (Table 1). Regarding to adhesions qualification and quantification also there was no statistical significance difference between both groups (Table 2).

The tensiometric study was also similar. The experimental group showed a mean burst pressure of 144,0 $\mathrm{mmHg}$ and the control group showed a mean burst pressure of $133,67 \mathrm{mmHg}$. These differences were not statistically significant (Table 3).

TABLE 1 - Complications freqüency in both groups

\begin{tabular}{llll}
\hline Aspect & $\begin{array}{l}\text { Control } \\
(\mathbf{n = 1 5})\end{array}$ & $\begin{array}{l}\text { Experimental } \\
(\mathbf{n = 1 5})\end{array}$ & $\begin{array}{c}\text { P } \\
\text { Value }\end{array}$ \\
\hline Regular & 12 & 10 & \\
& $(80 \%)$ & $(66,67 \%)$ & 0,6817 \\
\hline $\begin{array}{l}\text { Complications } \\
\text { (abcess and }\end{array}$ & 3 & 5 & \\
intestinal fístulas) & $(20 \%)$ & $(33,33 \%)$ & \\
\hline
\end{tabular}

TABLE 2 - Frequency of adhesions quantification

\begin{tabular}{lll}
\hline $\begin{array}{l}\text { Adhesion } \\
\text { quantification }\end{array}$ & $\begin{array}{l}\text { Control } \\
(\mathbf{n = 1 5})\end{array}$ & $\begin{array}{l}\text { Experimental } \\
(\mathbf{n = 1 5})\end{array}$ \\
\hline 0 (absent) & 7 & 3 \\
& $(46,67 \%)$ & $(20,00 \%)$ \\
\hline 1 (thin) & 5 & 9 \\
& $(33,33 \%)$ & $(60,00 \%)$ \\
\hline 2 (fibrotic) & 3 & 3 \\
& $(20,00 \%)$ & $(20,00 \%)$ \\
\hline
\end{tabular}

In all animals the burst pressure rupture occurred outside the suture line. In the sections stained with H\&E, the qualitative histological evaluation, showed a similar inflammatory feature regarding to edema, however demonstrated a granuloma chronic inflammatory process statistically less pronounced $(p=0,0209)$ (Figure 2$)$ in the experimental group. In qualitative evaluation, the experimental group presented a smaller granulation area in comparison with the control group $(\mathrm{p}=0,0099)$ (Figure 3 ), these difference was statistically significant. The gap distance between the anastomosis loops and the angiogenesis area were similar between both groups.

The Cross-polarization microscopy revealed similar amounts of total collagen $(p=0.9025)$, while the percentage of immature collagen was greater in the experimental group $(p=0,009)$ (Figure 4$)$ and consequently the ratio of collagen type I to type III was lower. The histological evaluation results are demonstrated by the Table 4 .

TABLE 3 - Bursting Pressure study in $\mathrm{mmHg}$

\begin{tabular}{|c|c|c|c|}
\hline Group & Median & Mean +-d.p & $\mathbf{P}$ \\
\hline Control & 135 & $\begin{array}{l}133,67 \\
+-29,18\end{array}$ & \multirow{2}{*}{0,2017} \\
\hline Experimental & 140 & $\begin{array}{l}144,00 \\
+-34,24\end{array}$ & \\
\hline
\end{tabular}

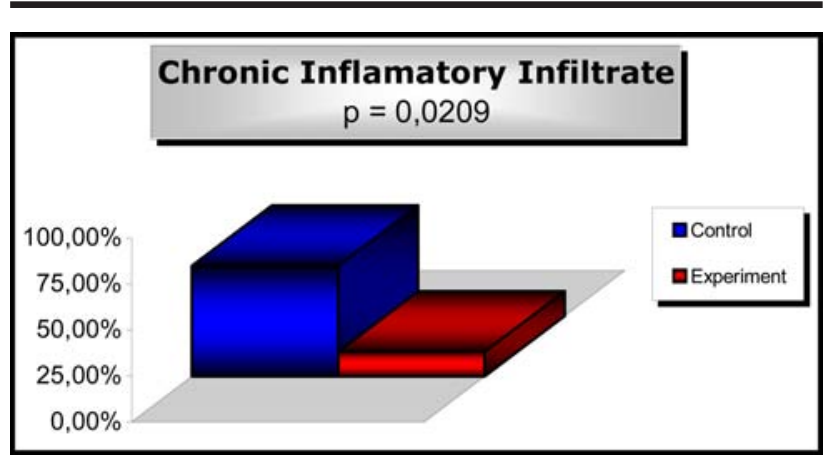

FIGURE 2 - Predominance of chronic inflammatory infiltrate in control group

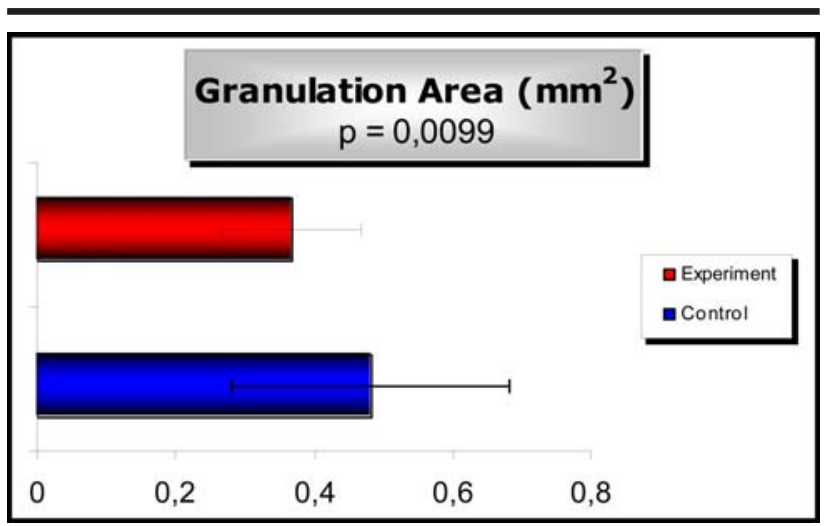

FIGURE 3 - Lesser granulation area in experiment group 
TABLE 4 - Histological evaluation abstract of sections stained with HE and Sirius Red

\begin{tabular}{|c|c|c|c|c|}
\hline Variables & & $\begin{array}{l}\text { Control } \\
(n=15)\end{array}$ & $\begin{array}{l}\text { Experimental } \\
(n=15)\end{array}$ & $\mathbf{P}$ \\
\hline \multirow[t]{2}{*}{ Angiogenesis área $\left(\mathrm{mm}^{2}\right)$} & Mean & 219,60 & 235,20 & \\
\hline & $\pm \mathrm{dp}$ & $\pm 64,57$ & $\pm 47,12$ & 0,4610 \\
\hline \multirow[t]{2}{*}{ Epithelization distance (mm) } & Mean & 0,1413 & 0,1700 & \\
\hline & $\pm \mathrm{dp}$ & $\pm 0,0579$ & $\pm 0,0472$ & 0,1261 \\
\hline Chronic Inflamatory Infiltrated (\%) & Freqüency & $9(60 \%)$ & $2(13,33 \%)$ & 0,00209 \\
\hline \multirow[t]{2}{*}{ Granulation Área $\left(\mathrm{mm}^{2}\right)$} & Mean & 0,4820 & 0,3673 & \\
\hline & $\pm \mathrm{dp}$ & $\pm 0,1527$ & $\pm 0,0542$ & 0,0099 \\
\hline \multirow[t]{2}{*}{ Densitometry of Colagen (Imature Collagen) $(\%)$} & Mean & $53,31 \%$ & $70,76 \%$ & \\
\hline & $\pm \mathrm{dp}$ & $\pm 11,29$ & $\pm 9,47$ & 0,0004 \\
\hline \multirow[t]{2}{*}{ Total Amount of Collagen } & Mean & $0,6560 \pm$ & 0,6535 & \\
\hline & $\pm \mathrm{dp}$ & 0,1492 & $\pm 0,1535$ & 0,9025 \\
\hline
\end{tabular}

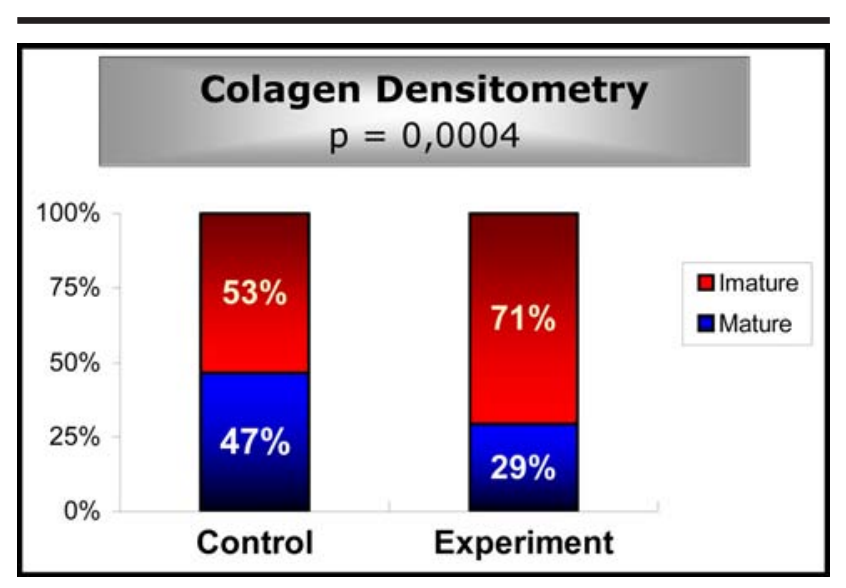

FIGURE 4 - Predominance of Immature collagen in experiment group

\section{Discussion}

Recent studies have started to describe the functions of specific molecules in the healing process. Mainly the Interleukin-6 (IL-6), showing its function as a multi functional cytokine in orchestrating physiological and patophisiological reply to diverse process, amongst the healing ${ }^{1,10}$. At the moment, there is no consensus about the specific function of this cytokine in healing ${ }^{13,14}$. To the best of our knowledge, the present study is the first to verify the influence of exogenous administration of IL-6 in the healing of colonic anastomoses in rats. Similar studies, as Ishimura ${ }^{7}$ used an IL-6 inductor, the LPS, and others studies had evaluated the levels of IL- 6 under different conditions ${ }^{5,6,10}$. ISHIMURA ${ }^{7}$ verified that the group with more liberation of IL-6, had a less survival rate and present a harmful healing of intestinal anastomosis. In our study we didn't observe any mortality in both groups. ASHCROFT ${ }^{15}$ verified that the anesthetic Alfetanil increases the liberation of IL-6 and indirectly worsens the healing process. Regarding to adhesion formation, many surgeons had used different attempts, to attenuate undesirable pro-inflammatory effects, like intra-peritoneal dextran ${ }^{18}$, tecidual plasminogen activator ${ }^{16}$ and steroids ${ }^{13}$. All attempts had resulted in a reduction of adhesions, having however, important complications as a reduction of total collagen with consequent reduction of tensile straight and imunossupresion in the case of steroids use $\mathrm{e}^{1316}$.

A previous study showed that the pre-operative administration of Interleukin-6 increases the adhesions formation, while pre-operative administration of neutralizing antibodies against IL-6 resulted in a reduction of this adhesion formation, without the adverse side effects observed in other attempts. It was a more selective immunosupression, at a molecular level ${ }^{14}$.

We observe that adhesions were present in both groups without any statistically significant difference. There was a significant reduction concerning the evolution to cronicity of the inflammatory infiltrated, reduction in the granulation area and predominance of immature collagen in the experimental group. The prolongation of the inflammatory phase of healing, associated with a predominance of immature collagen is expected to increase surgical complications, as colonic anastomosis dehiscence, abcesses and fistulas ${ }^{7}$,however these complications were similar between both sdtudied groups during the period of time used in this study. Despite the harmful effects of trauma and IL-6 on wound healing, Demetriades recommends primary colonic anastomosis in colonic injuries He believes that this procedure will not increase the mortality and morbidity in patients severe trauma ${ }^{19}$. Although our results showed any statistical difference regarding to mortality, morbidity, adhesions formation and burst pressure. Although there were no significative differences in the mortality, morbidity adhesion formation and anastomotic burst pressure, our results were consistent with prior studies that showed a harmful histologic wound healing (less evolution to cronicity, less granulation area and predominance of immature collagen) as consequence of IL-6 effect ${ }^{7,14}$. 


\section{Conclusion}

The results suggested that IL-6 impairs the colonic healing in rats, demonstrated by a longer and persistence inflammatory phase of wound healing associated with a predominance of immature collagen in the anastomotic area.

\section{References}

1. Biffl WL, Moore EE, Moore FA, Peterson VM. Interleukin-6 in the injured patient. Marker of injury or mediator of inflammation? Ann Surg. 1996; 224(5):647-64.

2. Kopf M, Herren Wiles MV, Pepys MB, Kosco-Vilbois $\mathrm{MH}$. Interleukin 6 Influences Germinal Center Development and Antibody Production via a Contribution of C3 Complement Component. J. Exp. Med. 1998; 188(10): 1895 - 1906.

3. Mateo RB, Jonathan SR, Jorge EA. Interleukin-6 activity in wounds. Am. J. Physiol. 1994; 266:1840.

4. Akira S, Taga T, Kishimoto T.: Interleukin-6 in biology and medicine. Adv. Immunol. 1993; 54:1.

5. Taniguchi T, Loido Y, Aiboshi J, Yamashita T, Suzaki S, Kurokawa A. The Ratio of Interleukin-6 to Interleukin10 Correlates with severity in Patients with Chest and Abdominal Trauma. J Am Emerg Med. 1999; V. 17, N 6.

6. Abecasis P, Gomes JA, Matos MR, Aguiar P. Interleukin6 as a severity index in intensive care medicine. R Port Med Int. 2000; V. 9, N 3.

7. Ishimura K, Tsubouchi T, Okano K, Maeba T, Maeta $\mathrm{H}$. Wound healing of intestinal anastomosis after digestive surgery under septic conditions: participation of local interleukin-6 expression. World J Surg. 1998; 22:1069-1076.

8. Hierholzer C, Kalff JC, Chakraborty A, Watkins SC, Billiar TR, Bauer AJ, Tweardy DJ. Impaired gut contractility following hemorrhagic shock is accompanied by IL-6 and G-CSF production and neutrophil infiltration. Dig Dis Sci. 2001; 46:230-41.

9. Crozier TA, Muller JE, Quittkat D, Sydow M, Wuttke W, Kettler D. Effect of anaesthesia on the cytokine responses to abdominal surgery. British Journal of Anaesthesia. 1994; 72:280-285.
10. Baker E, Leaper D. Proteinases, their inhibitors, and cytokine profiles in acute wound fluid. Wound Heal. Soc. 2000; ISSN 1067-1927.

11. Council for International Organization of Medical Sciences. Ethical code for animal experimentation. WHO Chronicle. 1985; 39(2):51-6.

12. Junqueira, LCU, COSSERMELLI W, BRETANI RR. Diferencial staing of collagen type I, II and III by Sirius red and polarization microscopy. Arch Histol Jpn. 1978; 41:267-74.

13. Kaidi AA, Nazzal M, Gurchumelidze T, Ali MA, Dawe EJ, Silva YJ. Preoperative administration of antibodies against tumor necrosis factor-alpha and interleukin-1 and their impact on peritoneal adhesion formation. Am Surg. 1995; 61;568-72.

14. Saba, AA., Kaidi AA., Godziachvili V. Effects of interleukin- 6 and its neutralizing antibodies on peritoneal adhesion formation and wound healing. Am. Surg. 1999; $62,569-572$.

15. Aschcroft GS, Masterson GR. Interleukin-6 and wound healing. Br J Anaesth. 1994; 73: 426.

16. Evans DM, McAree K, Guyton DP. Dose dependency and wound healing aspects of the use of tissue plasminogen activator in the prevention of intraabdominal adhesions. Am J Surg. 1993; 165:228-32.

17. Decherney A., Dizerega G. Clinical problem of intraperitoneal postsurgical adhesion formation following general surgery and the use of adhesion prevention barriers. Surg Clin Noth. Am. 1997, 77:3, 671-688.

18. Holmdahl L, Risberg B, Beck DE. Adhesions: Pathogenesis and prevention. Eur J Surg. 1997; 577: 56-62.

19. Demetriades D, Murray JA, Chan L. Penetrating colon injuries requiring resection: diversion or primary anastomosis? An AAST prospective multicenter study. J Trauma. 2001 May;50(5):765-75.

\section{Acknowledgment}

The authors thank Associate Professor Marcia Olandoski for the statistical analysis of this study and our staff of the laboratory of experimental surgery, represented by Mrs. Rosana Nunes, Mr. Misael Barbosa and Mr. Alvaro Machado.

\section{Correspondence:}

Fernando Hintz Greca

Av. Visconde de Guarapuava, 5087/1401

80240-010 Curitiba-Paraná Brazil

fernando.greca@bbs2.sul.com.br
Conflict of interest: none Financial source: none

Received: November 21, 2006 Review: December 14, 2006 Accepted: January 10, 2007

\section{How to cite this article:}

Greca FH, Souza Filho ZA, Giovanini A, Camargo Jr CA, Rubin MR, Silva RFKC. Interleukin-6 (IL-6) influence on colonic anastomosis healing in rats. Acta Cir Bras. [serial on the Internet] 2007 Mar-Apr;22(2). Available from URL: http://www.scielo.br/acb 